\title{
POLA MODUS OPERANDI FRAUD PEMBIAYAAN SERTA UPAYA MEMINIMALISIR KECURANGAN PADA BANK PERKREDITAN RAKYAT SYARIAH X
}

\author{
Purwanto \\ purwanto@unira.ac.is \\ Andriani Kusuma \\ Fakultas Ekonomi Universitas Madura
}

\begin{abstract}
The purpose of this study is to examine and explain the operandi pattern of fraud that occurs in the distribution of bank financing and explain the efforts to minimize fraud that occurs in the distribution of bank financing. The results of the study show that. This research is a type of qualitative research with the research design used is a case study in BPRS X. The data in this study consisted of documentation, interviews, and observations. The results showed that there were elements of BPRS $X$ who had practiced fraud starting from the submission stage, data analysis and approval in the form of falsifying documents by conditioning the submission so that they could pass the financing so that there were mask credit findings, credit in the name. As well as efforts to minimize fraud consisting of Pillar steps to prevent, detect, investigate and monitor and evaluate existing systems.
\end{abstract}

Keywords: Banking, Financing, Fraud

\section{ABSTRAK}

Tujuan penelitian ini adalah untuk Menelaah dan menjelaskan pola operandi kecurangan yang terjadi dalam penyaluran pembiayaan perbankan seta Menjelaskan upaya meminimalisir kecurangan yang terjadi dalam penyaluran pembiayaan perbankan. Hasil penelitian menunjukkan bahwa. Penelitian ini merupakan jenis penelitian kualitatif dengan Desain penelitian yang digunakan adalah studi kasus di BPRS X. Data pada penelitian ini terdiri dari dokumentasi, wawancara, dan observasi. Hasil penelitian menunjukkan bahwa terdapat oknum BPRS X telah melakukan praktik fraud mulai dari tahap pengajuan, analisa data dan persetujuan yang berupa pemalsuan dokumen dengan mengkondisikan pengajuan agar bisa lolos pembiayaannya sehingga terdapat temuan kredit topengan, kredit atas nama. Serta upaya meminimalisir fraud yang terdiri dari langkah-langkah Pilar pencegahan, deteksi, investigasi dan memantau serta mengevaluasi sistem yang ada.

Kata Kunci: Perbankan, Pembiayaan, Fraud

\section{PENDAHULUAN}

Fraud Menurut The Association of Certified Fraud Examiner (ACFE, 2016) didefinisikan sebagai tindakan seseorang memperoleh keuntungan, dengan cara yang tidak sesuai aturan serta unsur-unsur tak terduga, tipu daya, licik, dan tidak jujur yang dapat merugikan orang lain, sedangkan menurut Surat Edaran Bank Indonesia no. 13/28/DPNP yang dimaksud dengan Fraud adalah tindakan penyimpangan atau pembiaran yang sengaja dilakukan untuk mengelabui, menipu, atau memanipulasi bank, nasabah, atau pihak lain, yang terjadi di lingkungan bank dan/atau menggunakan sarana bank sehingga mengakibatkan bank, nasabah, atau pihak lain menderita kerugian dan/atau pelaku Fraud memperoleh keuntungan keuangan baik secara langsung maupun tidak langsung.

Hasil penelitian ACFE yang dituangkan dalam report to the nations on occupational fraud and abuse (2016) menyebutkan bahwa sektor perbankan dan jasa keuangan memiliki tingkat kecurangan paling tinggi yaitu sebesar 17,8\% dari total keseluruhan kasus yaitu $20 \%$. 
Menurut Hutauruk (2014) dalam prosedur dalam pemberian kredit ada yang tidak sesuai dengan prosedur. Hambatan yang terjadi dalam prosedur pemberian pembiayaan adalah keterlambatan dalam sistem pencairannya apalagi dalam pemberian kredit dengan jumlah besar, pengurus bank masih belum mendapatkan solusi yang tepat untuk mengatasi masalah tersebut. Sedangkan penelitian yang membahas tentang modus operandi fraud perbanakan dilakukan oleh Budianto (2011) menekankan bahwa terminologi, kejahatan korporasi dapat berupa: crimes for corporation; crime against corporation; dan criminal corporation. Jika kita melihat pada undang-undang perbankan, hanya kejahatan terhadap perizinan saja yang memberikan ancaman terhadap korporasi sebagai pelakunya. Dalam arti bahwa lembaga perbankan sebagai subjek dalam tindak pidana tersebut.

Berbagai penelitian diatas membuktikan bahwa tindakan fraud mustahil untuk dihilangkan, namun memungkinkan berkurang dengan memahami alasan yang menyebabkan penipuan dan mengambil tindakan proaktif terhadap fraud, salah satu cara dengan penelitian fraud perbankan yang berfokus pada sektor perkreditan/pembiayaan yang berkaitan dengan faktor pemicu fraud kredit perbankan guna bertujuan untuk peyempurnaan, terhadap celah dari pencegahan dan deteksi yang telah ada sebelumnya, hal ini penting untuk diteliti karena meskipun, dengan memahami faktor pemicu fraud, perbankan diharapkan akan dapat melakukan upaya dalam meminimalisir faktor pemicu fraud tersebut dalam hal ini yang menjadi objek peneltian adalah bank perkreditan rakyat (BPR) karena menurut data statistik perbankan indonesia tahun 2017 jumlah BPR jauh melebih jumlah bank umum dengan jumlah bank umum sebanyak 115 sedang BPR sebanyak 1.619.

Ditegaskan juga dalam penelitian Syafriansyah, (2015), menyatakan terdapat masalah-masalah yang menghambat kelancaran dalam prosedur pemberian kredit, yaitu tidak konsisten dalam menjalankan prosedur pemberian kredit, Salah satu penyebab meningkatnya fraud yang terjadi disektor perbankan adalah terdapatnya campur tangan pihak internal perbankan. Menurut Holtfreter (2005) tindakan kecurangan yang dilakukan oleh pegawai dapat terjadi karena perilaku yang berhubungan dengan moral dan kejujuran disebut Occupational crime. Hal ini terjadi akibat banyak kontrol anti-fraud yang harusnya menjadi efektif dalam upaya pencegahan fraud oleh sebagian besar organisasi malah diabaikan. Misalnya, monitoring dan analisis data proaktif. Perbankan memiliki pencegahan anti fraud yang sudah tercantum dalam Peraturan Bank Indonesia Nomor 11/25/PBI/2009 yang harus dijalan oleh setiap lembaga perbankan di Indonesia berupa 4 pilar yaitu pencegahan, dekteksi pemantauan dan investigasi.

Fenomena ini penting untuk diteliti karena meskipun perbankan memiliki system anti fraud yang diterapkan sangat ketat dibanding sector bisnis lainnya, namun tetap perbankan berada pada urutan pertama untuk bidang bisnis dengan kasus terjadinya fraud terbanyak tentu ini adalah fenomena yang ganjil dan perlu dilakukan kajian lebih dalam tentang pola operandi fraud seperti apa yang dapat membuat sistem yang begitu kuat dan ketat tetap masih sangat rentan terhadap fraud. Hal ini yang menjadikan Bank Perkreditan Rakyat Syariah (Bprs) X sebagai objek penelitian, dikarenakan perbankan yang berfokus pada kredit yang mengalami banyak tindakan fraud dalam penyaluran kreditnya. hal ini menjadi dasar dalam melakukan penelitian fraud kredit perbankan.

\section{METODE}

Peneliti ingin menganalisis pola fraud pada kredit perbankan yang menjadi temuan internal audit pada BPRS X melalui penggambaran secara rinci dari berbagai sumber informasi. Penelitian ini akan dilaksanakan BPRS $X$ yang dalam hal ini adalah penyelenggara bisnis perbankan yang telah banyak membantu dalam mengungkapkan berbagai jenis kecurangan, sehingga penulis dapat mengungkap modus operandi yang terjadi didunia perbankan. Informan internal dalam penelitian ini adalah kepala internal audit dan 
kepala pembiayaan pada BPRS X dengan masa kerja berkisar dari 3 sampai 7 tahun. Dalam kaitan dengan tugas sebagai intenal audit, informan cukup berpengalaman, terbukti dengan masa tugas di atas 2 tahun.

Peneliti melakukan wawancara terhadap kepala pembiayaan karena kepala pembiayaan adalah informan yang dapat menjelaskan secara detial tentang prosedur pembiayaan, serta kendala dalam melakukan realisasi pembiayaan yang terjadi dalam perusahaan tersebut sebab bersinggungan langsung dengan tugas dan tanggung jawabnya sebagai marketing perusahaan. Para informan yang terlibat dalam penelitian ini digambarkan pada tabel berikut:

Tabel 3.1

Distribusi Narasumber

\begin{tabular}{|l|c|l|}
\hline Nama* & Usia & Jabatan \\
\hline Mr. Hasyim & 46 Tahun & Kepala Internal Audit \\
\hline Mr. Halim & 43 Tahun & Kepala Pembiayaan \\
\hline
\end{tabular}

*bukan nama sebenarnya

Proses pengumpulan data pada penelitian ini terdiri dari dokumentasi, wawancara, dan observasi. Penelitian ini berawal dari pengamatan hasil Berdasarkan temuan internal audit, kemudian peneliti melakukan wawancara dengan para informan untuk mendapatkan pemaknaan dari masing-masing informan terkait temuan tersebut. Pengumpulan data dalam penelitian ini adalah wawancara langsung dan mendalam (depth interview). Wawancara dilakukan secara formal dan dalam satu kesempatan, di sela-sela informan menjalankan kesehariannya sebagai internal audit.

Peneliti mengikuti keseharian informan agar mendapatkan informasi yang lengkap terutama terkait kegiatan yang dilakukan informan. Teknik wawancara dilakukan secara santai agar informan dapat memberikan informasi secara alami tanpa adanya tekanan. Setelah data dan informasi terkumpul, hal pertama yang dilakukan adalah memilah, mengelompokkan data dan mereduksi (membuang data yang tidak berhubungan dengan penelitian). Selanjutnya peneliti dapat membentuk pola dan memilah, mengelompokkan data dan mereduksi data sampai mendapatkan simpulan.

\section{HASIL DAN PEMBAHASAN}

Ketika berada di BPRS X, peneliti merasakan situasi yang santai tan akrab ketika berhadapan dengan para informan. Peneliti merasa informan merasa leluasa memberikan informasi yang berkaitan dengan tugas yang beliau jalani setiap harinya, saat ditanyakan tentang tentang masalah prosedur pembiayaan dan penyimpangan yang terjadi didalamnya informan sangat kooperatif menjawabnya. Hal ini disebabkan karena waktu penelitian ini informan juga sedang berusaha lebih memperbaharui sistem internal control perusahaan dan berharap dari penelitian ini ada suatu output yang bisa dipakai dalam perbaharuan sistem di BPRS X. Selain fraud pembiayaan yang dijabarkan diatas, internal kontrol juga menemukan fraud pada mark up pembiayaan, pembiayaan rekayasa, agunan dan jaminan fiktif, profil usaha fiktif, lapping angsuran.

Temuan-temuan ini mendukung penelitian Junaedi (2013) bahwa nasabah-nasabah sontoloyo yang kini mengancam perbankan, mereka bergentayangan dengan yang potensial adalah pembiayaan fiktif atau mark-up pembiayaan yang nilainya mencapai puluhan triliun yang menunjukkan bahwa risiko operasional dengan sistem manajemen risiko dan reguler 
tidak berjalan dengan baik. Sejalan dalam kaitan risiko operasional dan dalam mencegah kejahat perbankan dimasa datang tidak hanya sekadar menetapkan kebijakan tentang fit and proper test tapi harus melakukan perbaikan terus menerus untuk meminimize risiko. Temuan-temuan internal kontrol terkait fraud pembiayaan merupakan sebuah fenomena yang sering dijumpai oleh internal kontrol meskipun perbaikan sistem terus dilakukan namun fraud tersebut tetap saja terjadi, hal menjadi pukulan telak bagi kepala internal audit hasyim yang sudah menjabat selama 9 tahun sebagai sebagai kepala internal kontrol BPRS $\mathrm{X}$, menurut narasumber fraud yang terjadi dalam pembiayaan adalah pembiayaan fiktif.

"[Menyandarkan tubuhnya ke kursi kerja dan dalam suasana santai] kami itu mas setiap tahun selalu mengevaluasi sisitem pengawasan di SOP kami tapi masih saja ada pembiayaan yang dipakai tapi bukan debitur sendiri yang pakai sampai bingung saya mas mau dibuat seperti apa sistem itu".

Hasyim yang sudah menjabat sebagai kepala internal audit selama 9 tahun merasa kebingungan dengan fraud yang terjadi pada bagian pembiayaan sebab dirinya dan tim selalu melakukan pembaruan sistem pengawasan namun tetap saja terjadi fraud yang berupa pembiayaan fiktif/topengan. Apalagi yang dilakukan debitur nakal itu tergolong sangat rapi dan terencana.

"[Dengan sedikit raut muka kecewa] kemaren itu mas yang lebih canggih ada tentang pembiayaanf fiktif/topengan disuatu daerah bendahara petani, pedagang semuanya dibuatkan SK seperti pegawai negeri tanda tangannya ditembak semua dan itu besar".

Raut muka yang sedikit kecewa dan bingung tergambar di wajah hasyim. Merasa pembaruan yang dia lakuakan dan tim selama ini masih kurang ketat sehingga masih terjadi fraud dalam pemberian pembiayaan, namun hasyim masih merasa optimis untuk terus bisa menemukan serta mendeteksi lebih awal potensi fraud yang akan terjadi dan lebih teliti dalam melaksanakan tugasnya. Sebuah sistem berjalan dengan baik jika semua stafnya menjalankan sesuai peraturan yang ada dan benar mekakukan seleksi debitur sesuai dengan ketentuan, namun pada faktanya ada staf yang justru malah berpihak pada debitur guna meloloskan pengajuan pembiayaan hingga tahap realisasi, hal ini yang dirasakan oleh halim sebagai kepala pembiayaan terhadap beberapa staf bawahnya.

"Kita kan komite itu melihat data yang diajukan oleh account officer yang betanggung jawab dan tahu keadaan sebenarnya dilapangan itu ya AO tdi, AO itu harusnya ada dipihak bank tapi kadang ada AO yang malah berpihak pada debitur guna mempertahankan debiturnya tersebut dan itu tidak pas kalau sudah seperti itu biasanya akan terjadi fruad. [Melihat ke arah peneliti dan dengan suara yang tegas serta bijak]".

Informasi yang terlontar dari ucapan halim ini mengisyaratkan terdapat beberapa oknum dari dalam perusahaan sendri yang justru malah membantu terjadi fraud dengan tidak menjalankan prosedur dengan benar. Nadanya yang tegas menunjukkan bahwa ia sangat tidak mentoleransi ke berpihak para oknum tersebut karena akan menimbulkan potensi fraud serta merugikan pihak bank. Lebih lanjut halim mengatakan bahwa kesalahan yang fatal bagi seorang AO adalah jika dia sampai membuat data palsu demi meloloskan debiturnya dan akan sangat berisko bagi AO yang bersangkutan. 
"Kegagalan marketing itu bermacam-macam mas, tapi yang paling fatal kalau sudah marketing membuat data secara fiktif tapi itu akan segera ketahuan."

Halim merasa selama ini ia tidak mentoleransi jika ada bawahannya yang melakukan tindakan rekayasa data. Ia menganggap bahwa bahwa ke berpihak terhadap debitur akan merusak sistem perusahaan dan akan banayak terjadi fraud sedang pembiayaan sendri memiliki target NPL 1,2\%. Fraud yang terjadi di BPRS X ini khususnya pada bagian pembiayaan merupakan hal yang selalu diantisipasi sebelumnya. Pengalaman para informan yang selama ini fraud tersebut selalu terjadi meskipun sudah banyak melakukan pembaruan sistem pengawasan. Apalagi dalam hal ini ada pihak internal perusahaan yang malah membantu terjadinya potensi fraud tersebut. Secara umum informan berpendapat bahwa dengan adanya kejadian ini memberikan pelajaran bagi mereka untuk lebih berhati-hati dalam melakukan tugasnya sehingga terjamin aman dan terbebas dari fraud.

Tahap awal peneliti akan mengulas tentang temuan Audit internal pada BPRS X. Berdasarkan berdasarkan standar pengawasaan sebagaimana Surat Edaran Bank Indonesia No.14/ 26 /DKBU tentang standar pelaksanaan Audit Intern Perpembiayaanan guna mencegah terjadi fraud dalam perbankkan yang meliputi Fungsi untuk memantau kinerja sistem pengendalian intern serta memastikan bahwa pelaksanaan perpembiayaanan telah dilakukan dengan benar sesuai dengan Pedoman Kebijakan Perpembiayaanan BPR (PKPB). Laporan Hasil Pemeriksaan audit internal banyak nemukan fraud pada pemberian pembiayaan antara lain Pemalsuan dokumen pembiayaan Mark-up nilai jaminan, Pembiayaan fiktif, dan topengan. Adanya peraturan yang ketat oleh bank indonesia dan OJK terhadap pengawasan pemberian pembiayaan tidak serta merta menghilangkan fraud pada perbankan, namun fraud tetap saja terjadi dan jumlahnya terus bertambah hal ini merupakan fenomena yang menarik dibahas. Salah satu pokok temuan tersebut adalah realisasi pembiyaan pada kelompok tani yang ternyata pembiayaan topengan dan tidak didukung bukti dokumen yang riil. Ini berarti bahwa dalam prosedur pembiayaan terindikasi melakukan fraud.

Internal kontrol menilai bukti dokumen tersebut tidak riil karena bukti dokumen tidak sesuai dengan pengajuan awal tentang pengguna pembiayaan tersebut (pembiayaan topengan). Selain itu internal kontrol juga menemukan bahwa tanda tangan dalam persetujuan pembiayaan kelompok tani tersebut tidak dengan sepengtahuan anggotanya. Hal ini diketahui setelah internal kontrol melakukan konfirmasi langsung dengan para anggota kelompok tani tersebut. Hal ini berarti internal kontrol telah menemukan 2 pola fraud yang dilakukan nasabah yakni adanya bukti dokumen yang fiktif dan adanya pemalsuan tanda tangan anggota kelompok tani. Temuan inetrnal control ini (2 pola fraud yang dilakukan debitur dalam prosedur pembiayaan) dijadikan peneliti sebagai pijakan untuk menggali lebih dalam lagi tentang pola fraud pada pembiayaan yang menjadi temuan internal kontrol.

Fraud pada Tahap Pengajuan Berdasarkan observasi kegiatan pengelolaan pembiayaan BPRS X, peneliti menemukan bahwa sebenarnya praktik fraud sudah dimulai dalam tahap prosedur pemberian dan pengajuan pembiayaan. Prosedur pemberian dan pengajuan pembiayaan dimulai dengan pengajuan dokuman dari debitur pada AO yang kemudian diproses lebih lanjut, dalam hal ini banyak pontensi fraud yang terjadi baik dari debitur maupun dari ao yang bersangkutan yang potensial dilakukan dalam pemalsuan dokumen, baik itu identitas diri, profil usaha, agunan dan jaminan yang bertujuan meloloskan pengajuan tersebut sehingga terjadi realisasi dari bank. Menurut kepala audit biasanya pemalsuan dalam tahap prosedur pengajuan pembiayaan ini pelaku memberikan data palsu pemakai dana,dan untuk jaminan bukan atas nama pribadi dari debitur yang bersangkutan. 
Kepala audit mengatakan:

"Setiap pengajuan kita itu harus periksa betul-betul, kadang ada nasabah dan AO kita yang nakal yang pengajuan sama pemilik jaminan itu berbeda kadang ada mas yang jaminannya dimark up supaya mengcover pinjaman ".

Hasyim berpendapat tidak sedikit nasabah dan AO yang bermain curang saat pengajuan permohonan pembiayaan, mulai dari KTP yang dipalsukan agar bisa masuk pada wilayah AO yang bersangkutan, juga ada yang memberikan informasi palsu tentang kegiatan usaha mereka tujuannya untuk membuat seolah-olah pengajuan yang mereka lakukan sesuai peraturan dan tidak menyimpang. Penyimpangan dalam pengajuan pembiayaan menimbulkan masalah tersendiri pada saat harus mempertanggungjawabkan. Dapat dipastikan dokumen pengajuan tersebut bersifat fiktif (semua atau sebagian). Hal ini sesuai dengan temuan internal audit yang menunjukkan hampir setiap tahun di BPRS X ditemukan fraud pada pengajuan pembiayaan. Selain itu, dalam prosedur pengajuan seringkali ditemui adanya campur tangan pihak intern bank (marketing, AO), artinya pihak intren bank yang harusnya berada pada pihak bank dan menjaga agar bank menjalankan kegiatannya sesuai dengan peraturan yang ada agar terhindar dari resiko justru malah membantu debitur nakal agar cepat ter-realisasikan . Misalnya saja saat pengajuan AO memasukkan data debitur pada SID(sistem identitas debitur) meskispun data-datanya tidak lengkap guna mempercepat proses pengajuan, harusnya dalam hal ini tidak diperbolehkan karena akan menyebabkan potensi fraud yang berakibat juga nantinya pada analisa 5C yang akan tidak sesuai dengan keadaan sebenarnya.

Pada prosedur pengajuan juga ditemui adanya mark up taksasi jaminan. Nilai harga pasar jaminan yang diberikan oleh AO terhadap debitur yang dibawanya jauh melebihi harga di pasaran. Dalam penentuan harga pasar harus berdasarkan standar harga pasar yang ditetapkan melalui Peraturan perusahaan. Menurut peraturan BI NOMOR 13/ 26 /PBI/2011 menjelaskan bahwa pembiayaan dengan jaminan kendaraan bermotor harus $50 \%$ dari nilai pasar. Hal ini dilakukan untuk menutupi resiko jika sewaktu-waktu ada masalah dengan debitur yang bersangkutan. Pada praktiknya harga pasar dri jaminan dihitung lebih guna mencover nilai pembiayaan yang di inginkan debitur, padahal jaminannya sesungguhnya tidak bisa mengcover. Hal ini mengakibatkan adanya selisih harga taksasi dan lagi- lagi terjadi inefisiensi dalam prosedur pengajuan pembiayaan.

Fraud Pada Tahap Pengolahan dan Analisa Data, Bagaimana mungkin proses pengolahan data dan analisa dokumen bisa berjalan dengan benar bila proses pengajuan saja sudah terdapat praktik fraud. AO dan marketing selalu berusaha "meloloskan" semua debitur yang dia ajukan dokumen pembiyaannya, kurang peduli terhadap kebenaran dokumen tersebut.

halim menuturkan:

"Marketing dan AO itu punya target setiap bulannya meraka berfikir bagaimana cara target terpenuhi itu yang bisa menyebabkan keberpihakkan kepada debitur".

Dokumen dengan Kondisi "terlalu memaksakan" inilah yang membuat merajalelanya praktik fraud. Dokumen dibuat seolah-olah 100\% sesuai dengan ketentuan bank meski sesungguhnya semua riilnya tidak demikian. Pencapaian target pembiayaan yang lebih rendah dari target dinilai sebagai sebuah kegagalan marketing dan AO dalam melaksanakan tanggungjawabnya. Hal ini menyebabkan adanya adanya dokumen fiktif. AO biasanya meminta kelengkapan dokumen pada debitur mulai dari Ktp,Kk,Slip Gaji,Blanko Pengajuan Pembiayaan yang telah diisi,dokumen kepemilikan jaminan yang nantinya 
dianalisa berdasarkan SEBI No.14/ 26 /DKBU/2012 dengan analisa 5C namun dalam tahap ini fraud banayak terjadi.

Analisa yang dilakukan tidak mencerminkan keadaan debitur sebenarnya dengan cara memanipulasi data. analisa Character dalam analisa ini biasa AO melakukan survei dengan cara wawancara pada debitur untuk mengetahui bagaimana karakter debitur namun dlam prakteknya AO tidak melakuan wawancara namun mengarang sendri narasi karakter agar sesuai dengan ketentuan, analisa Capacity digunakan untuk menetukan kemampuan bayar dari debitur terhadap pembiyaan yang diajukan dengan cara meminta sumber pemasukan dana debitur setiap bulannya dalam prakteknya AO melakukan mark -up terhadap kemapuan bayar debitur agar debitur dapat lolos dalam analisa, analisa Capital ditujukan untuk melihat jumlah aset dan kekayaan dari debitur guna menjamin keamanan pembiayaan jika terjadi masalah nantinya dalam prakteknya AO melakukan mark -up terhadap aset yang diimiliki debitur agar debitur dapat lolos dalam analisa.

Analisa Condition melihat prospek lingkungan disekitar tempat tinggal debitur apakah layak dengan pengajuan yang debitur ajukan dalam prakteknya kondisi debitur dibuat agar menjadi baik dan mampu dalam melakuakan pembiayaan, analisa Collateral digunakan untuk meliahat apakah jaminan aset dari debitur dapat mengcover pembiyaan yang diajukan apabila terjadi masalah dalam pembiayaan tersebut prakteknya ao membuat seolah-olah jaminan yang diajukan sesuai dengan ketentuan dan mampu mengcover dari pembiayaan yang di ajukan. Menurut hasyim praktek ini sering dilakuakn oleh ao guna melolokan pembiayaannya sampai tahap realisasi karena ao dapat memenuhi targtenya.

Berikut menurut hasyim:

"Biasanya kalo dalam analisa data ao itu manipulasi datanya pas analisa 5c semua dibuat bagus seperti layak untuk diberi pembiayaan, tapi setelah realisasi ada nunggak, ada yang jaminannya disita itu karna ao terlalu mementingkan targetnya". Secara keseluruhan proses tahap pengolahan dan analisa data pembiayaan di BPRS $\mathrm{X}$ tidak sepenuhnya dilakukan $100 \%$. Ada beberapa analisa yang tidak $100 \%$ riil dilakukan. Administrasi yang dilakukan sudah lengkap, namun tidak ada yang bisa menjamin kebenaran yang tertera dalam dokumen. Pemalsuan dokumen merupakan bentuk fraud.

Fraud Pada tahap akhir persetujuan pembiayaan pembiayaan di BPRS X, komite pembiayaan sangat berperan penting. Komite pembiayaan merupakan verifikator internal BPRS X. Ia selaku verifikator yang bertanggungjawab meneliti kelengkapan dokumen yang dibuat oleh marketing dan melakukan verifikasi dokumen penatausahaan yang dibuat marketing. Selain itu ia juga bertugas melaksanakan fungsi merekomendasikan dan menolak pengajuan pembiayaan.

Berdasarkan pengamatan peneliti, komite pembiayaan telah memferivikasi dokumen pembiayaan sesuai SEBI no.14/ 26 /DKBU tahun 2012. Ia memeriksa kelengkapan dokumen pembiayaan dan keabsahan bukti-bukti dokumen yang disampaikan marketing/AO. Ia juga menganalisa kelayakan pemberian pembiyaan dan menguji kebenaran sesuai dengan kelengkapan dokumen pengajuan pembiayaan. Selain sebagai verifikator pertama, komite pembiayaan juga bertanggung jawab dalam pemberian persetujuan pembiayaan secara profesional, jujur, obyektif, cermat, seksama, dan independen tanpa dapat dipengaruhi pihak-pihak manapun. Mereka bekerja berdasarkan data, informasi dan dokumen pendukung dari marketing/AO, yang dokumennya tidak terlepas dari unsur fraud.

Sesuai pengamatan peneliti, selama proses persetujuan pembiayaan yang dilakukan oleh komite pembiayaan dari dokumen yang diajukan marketing/AO, Setelah menerima 
data, informasi, dan dokumen dari AO mereka melakuakan analisa dan memastikan bahwa setiap pembiayaan yang diberikan telah memenuhi ketentuan perbankan dan sesuai asas-asas perpembiayaanan yang sehat. Proses persetujuan pembiayaan dilaksanakan berdasarkan SEBI no.14/ 26 /DKBU tahun 2012 tentang Pedoman Kebijakan dan Prosedur pembiayaan Bagi Bank Perpembiayaanan Rakyat. Dapat dikatakan secara umum bahwa persetujuan pembiayaan sudah sesuai dengan aturan.

Hal yang menjadi pertanyaan sekarang adalah bagaimana dengan kebenaran dokumen pengajuan yang dibuat. Apakah ada jaminan isi dari dokumen pengajuan tersebut telah benar meskipun prosesnya sudah sesuai aturan. Sebagaimana dikemukakan di atas bahwasannya mulai proses pengajuan dan analisa data saja sudah sarat dengan unsur fraud. Lalu bagaimana dengan tahap akhir persetujuan yang dihasilkan.

Sebagaimana diketahui bahwa dalam proses persetujuan pembiayaan oleh komite pembiayaan, bekerja berdasarkan data, informasi dan dokumen dari marketing/AO. Data awal dan pendukung yang diinput ke dalam dokumen telah diragukan kebenarannya. Lalu bagaimana mungkin proses persetujuan yang dihasilkan dapat dikatakan terbebas dari fraud.

Halim berujar:

"Kami sebagai komite pembiayaan setelah dokumen pengajuan lengkap dari marketing baru kita komite-kan berdasar dokumen tersebut kami memberikan keputusan layak tidaknya debitur itu diberikan pembiayaan".

SEBI no.14/ 26 /DKBU tahun 2012 telah menyebutkan bahwa Prosedur pembiayaanan Bagi Bank pembiayaanan Rakyat yang terdiri dari 3 tahapan yaitu pengajuan; analisa dan persetujuan. Ketiga tahapan tersebut merupakan satu kesatuan dan saling terkait. Apabila dari tahapan awal (pengajuan) sudah ada "permainan" dan di tahapan kedua (analisa) sudah ada "pengkondisian dan mempercantik kondisi debitur" lalu bagaimana mungkin hasil dari tahap ketiga (persetujuan) dapat benar $100 \%$.

Komite pembiayaan bisa mengatakan bahwa mereka sudah bekerja sesuai standar yang berlaku dan mengklaim telah benar dalam pemberian keputusan pembiayaan yang dihasilkan. Mereka boleh saja mengatakan bahwa praktik fraud hanya terjadi pada tahapan pengajuan dan analisa saja. Akan tetapi mereka tidak dapat mengelak kalau data input yang mereka gunakan sudah mengandung unsur fraud.

Beberapa hal yang kurang sesuai dengan prinsip syariah dan ketentuan Dewan Syariah Nasional yang diterapkan oleh BPRS X karena adanya prinsip kehati-hatian dan meminimalisir resiko dengan cara memaksakan akad. Ketidaksesuaian akad tersebut terjadi Pembiayaan modal (mudharabah atau musyarakah) dimana dalam ketentuannya untuk akad mudharabah adalah digunakan pembiayaan yang disalurkan oleh bank kepada pihak lain untuk suatu usaha yang produktif dimana dalam hal ini bank memberikan hak penuh pada nasabah untuk mengelola dana tersebut. Sedangkan akad musyarakah adalah digunakan pembiayaan yang disalurkan oleh bank kepada pihak lain untuk suatu usaha yang produktif dimana dalam hal ini bank ikut andil dalam pengelolaan usaha yang dijalankan nasabah sebagi rekan/mitra kerja. Namun pada penerapannya pihak bank membuat akad yang seharusnya Pembiayaan modal (mudharabah atau musyarakah) dipaksakan kepada akad jual beli (murabahah) dimana akad murabahah tersebut digunakan apabila nasabah mengajukan permohonan untuk bank agar dapat membiayai pembelian suatu barang yang diingikan oleh nasabah dengan pesyaratan tertentu. Langkah ini diambil bagi nasabah baru yang belum dikenal betul karakternya oleh pihak bank. 
Halim berujar:

"Biasanya kalau masih nasabah baru akadnya kita pakai murabahah atau akad jual beli karena kita belum tahu orang ini kareakter sesunguhnya, seperti apa, kami kan juga perlu meminimalisir resiko"

Pihak bank cenderung tidak mau mengambil resio terhadap nasabah baru yang dibawa oleh marketing dalam menjaga agar pemebiayaan yang diberikan dapat kembali dengan utuh pihak perlu melakukan pengikatan terhadap nasabah dan akad murabahah ambil sebagai pilihan menimalisir resiko serta terkesan enggan menanggung kerugian yang dialami oleh nasabah pada saat menjalankan usaha yang dijalani, dengan argumen bawah pihak bank sudah memberikan modal yang cukup untuk nasabah melakukan usahanya dengan lancar, pihak bank bersedia menanggun resiko apabila terjadi kematian atau bencana alam dalam menjalakan usaha tersebut, diluar dari ketentuan tersebut pihak bank menghitung bawah hal itu adalah kelalaian dari nasabah dan wajib mengembalikan $100 \%$ dana modal yang diberikan. Sesuai pengamatan peneliti, masih ada beberapa hal yang belum sesuai dengan prinsip syariah dan ketentuan Dewan Syariah Nasional, hal ini mengisyaratkan bahwa pengawasan yang dilakukan oleh DPS terhadap Produk-produk pembiayaan syariah masih belum optimal dalam menjalankan peran dan fungsi DPS pada perbankan Syariah.

Upaya meminimalisir fraud bisa diartikan sebagai upaya untuk memperbaiki sistem yang sudah tercemari tindakan fraud dan mencari solusi agar fraud tidak terulang kembali. Fraud dinilai sebagai sebuah penyakit yang menjangkit dan harus diminimalisir. Upaya meminimalisir fraud diawali dengan mempelajari gejala atau pola fraud yang terjadi. Selanjutnya melakukan diagnosis fraud untuk mengetahui akar penyebabnya. Dengan mengetahui akar penyebab terjadinya fraud, diharapkan bisa membantu dalam upaya mengatasi fraud.

Beradasarkan penyebab terjadinya fraud pada rincian prosedur pembiayaan yang menjadi temuan Internal Audit, peneliti membaginya dalam 2 kategori yaitu penyebab dari pribadi fraudster dan yang kedua penyebab adanya celah sistem. Oleh karenanya upaya meminimalisir fraud yang disusulkan oleh peneliti juga dibagi dalam penerapannya berupa 4 (empat) pilar sistem pengendalian Fraud yang terdiri dari langkah-langkah sebagai berikut : 1) Pilar pencegahan merupakan bagian yang mencakup anti Fraud awareness, identifikasi kerawanan, dan know your employee. 2) Pilar deteksi merupakan bagian yang kebijakan dan mekanisme whistleblowing, surprise audit, dan surveillance system. 3) Pilar investigasi, pelaporan, dan sanksi merupakan bagian yang mencakup tentang menggali informasi (investigasi), sistem pelaporan, dan pengenaan sanksi atas Fraud dalam kegiatan usaha Bank. 4) Pilar pemantauan, evaluasi, dan tindak Lanjut merupakan bagian yang mencakup tentang memantau dan mengevaluasi Fraud, serta mekanisme tindak lanjut. Dalam mengatasi fraud dibutuhkan sistem yang disusun sedemikian rupa agar bisa meminimalkan terjadinya fraud. Celah-celah aturan yang masih bisa menimbulkan fraud harus diperbaiki.

\section{Pencegahan}

Pilar pencegahan merupakan bagian dari sistem pengendalian Fraud yang memuat langkah-langkah dalam rangka mengurangi potensi risiko terjadinya Fraud, yang paling kurang mencakup anti Fraud awareness, identifikasi kerawanan, dan know your employee.

\section{Anti Fraud Awareness}

Berdasarkan hasil penelitian, narasumber dalam penelitian ini memberikan informasi yang cukup beragam mengenai Anti Fraud Awareness 
"Memang kalau saya lihat sih semacam program awareness terhadap anti Fraud ini sangat bagus, walaupun mungkin ini dalam prakteknya tidak dapat dijalankan secara optimal, sebab seperti penyusunan-penyusunan dalam organisasi bank pada umumnya yang saya amati sih jarang terjadi, kalaupun ada sifatnya temporer, misalkan ada program tertentu dari pemerintah, baru diadakan oleh bank dan itupun dibahas guna lebih memahami program tersebut"

Pernyataan diatas dapat disimpulkan kurang efektifnya program Anti Fraud Awareness dikarenakan hanya dilakukan bila ada peraturan baru yang dikeluarkan oleh pemerintah, hal ini menjadi sangat sayangkan karena harusnya pihak perbankan berperan aktif namun kurang kesadarannya dan masih menunggu upaya dari pemerintah.

\section{Identifikasi Kerawanan}

Berdasarkan hasil penelitian, maka narasumber dalam penelitian ini memberikan informasi yang cukup beragam mengenai program identifikasi kerawanan.

"Identifikasi kerawanan ini, didasarkan pada sejauhmana sebuah bank mengendalikan tindakan kecurangan yang akan atau mungkin terjadi di dalamnya, secara sistematis memastikan mana saja dalam sebuah aktivitas keorganisasian yang memiliki kerawanan tinggi terhadap kecurangan. Ini dilakukan agar mencegah tindakan oknum yang mungkin akan merugikan bank."

Pernyataan diatas dapat disimpulkan bahwa identifikasi kerawanan kerawanan sudah dijalankan oleh pihak bank dengan sebaik-baiknya agar mencegah resiko kerugian bank

\section{Know Your Employee}

Berdasarkan hasil penelitian, maka narasumber dalam penelitian ini memberikan informasi yang cukup beragam mengenai Know your Employee.

"Monitoring karyawan selama ini relatif berjalan baik. Walaupun tidak sedetil seperti pengenalan karakter dan gaya hidup karyawan. Tetapi kalau secara umum, aspek-aspek mengetahui karyawan itu sudah relatif berjalan dengan baik."

Pernyataan diatas memberikan informasi bahwa perbankan sudah menjalankan monitoring karyawan namun belum maksimal dan hanya sebatas pada monitoring kinerja saja yang semestinya pihak perbankan lebih aktif dalam mengenal kinerja karyawannya

\section{Deteksi}

Pilar deteksi merupakan bagian dari sistem pengendalian Fraud yang memuat langkah-langkah dalam rangka mendeteksi tindakan kecurangan, yaitu Whistleblowing, Surprise Audit dan Surveillance System.

\section{Whistleblowing}

Berdasarkan hasil penelitian, narasumber dalam penelitian ini memberikan informasi yang cukup beragam mengenai whistleblowing.

"Bagi saya, whistleblowing ini adalah kunci banyak terungkapnya tindakan kecurangan. Kalau program whistleblower ini berjalan dengan baik, maka itu mencerminkan komitmen tinggi bank dalam mengungkap tindakan Fraud. Namun sayangnya dalam hal ini belum berjalan dengan baik karena saksi masih engan melapor karena berbagai alasan meskipun tahu bawah ada fraud."

Sistem whistleblowing pada BPRS X dalam pernyataan tersebut masih belum berjalan dengan baik karena berbagai alasan sehingga saksi kejadian lebih memilih diam dan tidak melapor, hal ini disayangkan karena sebenarnya kunci terungkapnya fraud adalah laporan tersebut. 


\section{Surprise Audit}

Berdasarkan hasil penelitian, maka narasumber dalam penelitian ini memberikan informasi yang cukup beragam mengenai Surprise Audit.

"Justru audit yang seperti ini yang sangat membantu mengungkap tindakan-tindakan kecurangan yang terjadi. Reaksi-reaksi pelaku yang tentunya sudah merencanakan tindakan kecurangannya dan sedang melakukannya, tentu saja akan terdeteksi melalui program audit dadakan ini."

Surprise audit adalah upaya yang sangat efektif untuk mengungkap fraud menurut dari narasumber karena dapat mengungkap fraud yang sedang terjadi dengan cepat.

\section{Surveillance System}

Berdasarkan hasil penelitian, maka narasumber dalam penelitian ini memberikan informasi yang cukup beragam mengenai program surveillance sistem.

"Saya menilai sistem pengawasan adalah mutlak, apalagi dalam sektor perbankan, dan selama ini pengawasan yang ada dalam internal audit berjalan dengan relatif baik, walaupun terdapat kekurangan di sana sini."

Berdasarkan pernyataan diatas pihak BPRS X telah menjalankan surveillance sistem dengan baik, namun tidak dipungkiri masih banyak terdapat kekurangan yang menyebabkan pelaksanaannya tidak efektif.

\section{Investigasi}

Pilar investigasi, pelaporan dan sanksi merupakan bagian dari sistem pengendalian Fraud yang memuat langkah-langkah dalam rangka mendeteksi tindakan kecurangan. Berdasarkan hasil penelitian, maka narasumber dalam penelitian ini memberikan informasi yang cukup beragam mengenai program investigasi yang mencakup ketentuan penentuan tim investigasi dan pendekatan dan metodologi investigasi.

"Proses investigasi dalam mengungkap segala hal yang tersembunyi. Memastikan benar atau tidaknya, besar atau kecilnya risiko, dan kemudian menindaklanjutinya seandainya terjadi kecurangan ini dapat membantu dalam meminimalisir resiko yang dialami perbankan" Investigasi adalah upaya yang sangat efektif untuk mengungkap fraud menurut dari narasumber karena dapat mengungkap fraud yang sedang terjadi dengan cepat.

\section{Pelaporan (Internal, External)}

Berdasarkan hasil penelitian, maka narasumber dalam penelitian ini memberikan informasi yang cukup beragam mengenai program pelaporan yang terdiri dari standard dan system pelaporan investigasi.

"Semestinya, kalau ada yang diduga terjadi kecurangan ya harus dilaporkan. Karena kalau secara terus menerus diduga ada tindakann kecurangan, dan bank terkesan membiarkan, maka yang rugi itu bank. kalau sudah diinvestigasi pasti dilaporkan dan kecil kemungkinan untuk ditutup-tutupi, apalagi dalam kasus Fraud, karena pembiaran yang dilakukan merugikan bank itu sendiri."

Sistem pelaporan pada BPRS dalam pernyataan tersebut masih belum berjalan dengan baik karena berbagai alasan sehingga saksi kejadian lebih memilih diam dan tidak melapor, hal ini disayangkan karena sebenarnya kunci terungkapnya fraud adalah laporan tersebut

\section{Pengenaan Sanksi}

Berdasarkan hasil penelitian, maka narasumber dalam penelitian ini memberikan informasi yang cukup beragam mengenai program pengenaan sanksi yang terdiri dari 
kebijakan pengenaan sanksi, mekanisme pengenaan sanksi, dan penentuan pihak yang berwenang mengenakan sanksi.

"Sanksi merupakan salah satu bentuk tindakan bank untuk membuat jera para pelaku kecurangan atas kecurangan yang telah dilakukannya. Pengenaan sanksi juga dari pihak bank memberikan penguatan bagi kesadaran karyawan akan pentingnya bekerja profesional tanpa kecurangan".

Pernyataan diatas memberi kesimpulan Sanksi harus benar-benar ditegakkan dan apabila ada pelanggaran terhadap hukum tersebut, maka haruslah ada pemberian sanksi yang tegas seperti yang tertuang dalam strategi pencegahan ojk yaitu pengenaan sanksi atas Fraud dalam kegiatan usaha Bank. Pemberian sanksi diharapkan bisa memberikan efek jera kepada para fraudster.

\section{Pemantauan}

Pilar pemantauan, evaluasi \& tindak lanjut merupakan bagian dari sistem pengendalian Fraud yang memuat langkah-langkah dalam rangka memantau, mengevaluasi dan menindaklanjuti tindakan kecurangan, yang terdiri dari pemantauan, evaluasi dan sub pilar tindak lanjut. Berdasarkan hasil penelitian, maka narasumber dalam penelitian ini memberikan informasi yang cukup beragam mengenai program pemantauan yang terdiri dari program monitoring risiko Fraud dan program monitoring audit Fraud memiliki pandangan yang beragam.

"Pemantauan itu penting, tetapi tidak boleh mengabaikan aspek pemeliharaan sumber daya manusia yang harus terpelihara tingkat kesejahteraannya."

Hal ini memberi kesimpulan kurangnya pemantaun yang ketat terhadap kinerja karyawan hingga terjadi fraud dalam prosedur pembiyaan. Program pemantauan ini memiliki prospek baik karena pemantauan dapat membantu perusahaan sebagai pengendali sistem sebab sebuah sistem dapat bekerja dengan baik, bila seluruh elemen yang ada dapat berfungsi secara optimal.

\section{Evaluasi}

Berdasarkan hasil penelitian, maka narasumber dalam penelitian ini memberikan informasi yang cukup beragam mengenai program evaluasi yang terdiri dari program profiling Fraud dan evaluasi risiko Fraud.

"Saya menilai bahwa program evaluasi ini ya sangat baik, karena terkait dengan evaluasievaluasi guna memastikan sistem yang dijalankan sudah terawasi dengan ketat."

Hal ini memberi kesimpulan kurangnya evaluasi yang ketat terhadap sisitem hingga terjadi fraud dalam prosedur pembiyaan. Program evaluasi ini memiliki prospek baik karena evaluasi dapat membantu perusahaan sebagai pengendali sistem sebab sebuah sistem dapat bekerja dengan baik, bila seluruh elemen yang ada dapat berfungsi secara optimal

\section{Tindak Lanjut}

Berdasarkan hasil penelitian, maka narasumber dalam penelitian ini memberikan informasi yang cukup beragam mengenai program tindak lanjut yang meliputi mekanisme pelaksanaan tindak lanjut dan tindak lanjut atas program evaluasi risiko Fraud.

"Ini penting untuk ditindaklanjuti dan bank pun pastinya memiliki komitmen untuk itu karena kecurangan merugikan perusahaan, tidak hanya dari aspek finansial saja tetapi dari segi reputasi. Oleh karena itu program tindak lanjut memiliki prospek yang baik." 


\section{KESIMPULAN}

Fraud pada pembiayaan pada BPRS X. Pembahasan dimulai dari hasil temuan Audit internal pada BPRS X. Hasil penelitian menunjukkan bahwa terdapat oknum BPRS X telah melakukan praktik fraud mulai dari tahap pengajuan, analisa data dan persetujuan.

Fraud pada tahap pengajuan cenderung "pemalsuan dokumen". Pola yang dilakukan adalah dengan "mengkondisikan" pengajuan agar bisa lolos pembiayaannya. Sedangkan fraud pada tahap analisa data adalah dengan "memaksakan" kondisi debitur agar dapat pembiayaan $100 \%$. Pola fraud yang dilakukan yakni dengan malakukan analisa 5C sebagus mungkin agar debitur mendapat persetujuan pembiayaan. Pada tahap persetujuan BPRS X telah melaksanakan sesuai aturan yang berlaku. Berdasarkan observasi dan hasil wawancara, peneliti tidak menemukan adanya praktik fraud yang secara langsung dilakukan komite pembiayaan. Komite pembiayaan sudah bekerja sesuai aturan. Ia sudah meneliti kelengkapan dan melakukan verifikasi atas dokumen pengajuan pembiayaan yang disampaikan.

Komite pembiayaan juga telah melakukan fungsi pelaporan dan pertanggungjawaban sesuai prosedur, namun Apabila tahapan awal sudah sarat dengan fraud, maka hasil akhir dari serangkaian proses pengajuan pembiayaan juga tidak bisa dijamin benar $100 \%$. Komite pembiayaan yang menangani persetujuan bisa saja berkilah bahwa mereka sudah bekerja sesuai ketentuan dan tidak melakukan fraud, namun mereka juga tidak bisa mengelak bahwa data awal yang mereka gunakan dalam melakukan keputusan terindikasi fraud, sehingga analisa yang mereka lakukan pun juga terindikasi fraud. Serta pengawasan yang dilakukan oleh DPS terhadap Produk-produk pembiayaan syariah masih belum optimal dalam menjalankan peran dan fungsi DPS pada perbankan Syariah.

Upaya meminimalisir fraud fraud yang diawali dengan mengenali pola fraud pada pengelolaan pembiayaan. setelah itu dilanjutkan dengan menganalisis faktor-faktor yang menyebabkan terjadinya fraud pada pengelolaan pembiayaan yang menjadi temuan internal audit. Tahap terakhir adalah mencari solusi agar fraud pada pengelolaan pembiayaan yang menjadi temuan internal audit tidak terulang kembali. Upaya meminimalisir fraud. fraud pada pengelolaan pembiayaan yang menjadi temuan internal audit terdiri dari dua hal yaitu perbaikan sifat dan perilaku serta perbaikan sistem. Perbaikan sifat dan perilaku bisa dari dalam dan dari luar individu. Perbaikan dari dalam berupa memegang teguh ajaran agama islam dan norma- norma yang berlaku serta menjunjung tinggi integritas. Sedangkan perbaikan dari luar berupa memberikan teladan yang baik serta memberikan pelatihan dan pendidikan moral secara berkesinambungan serta menjain kesejahteraan karyawan.

Dalam Upaya meminimalisir fraud, perbaikan sistem perlu dilakukan untuk menunjang perbaikan sifat dan perilaku. Perbaikan sistem yang perlu dilakukan untuk mengatasi fraud pada pengelolaan pembiayaan yang menjadi temuan internal audit berupa menutup celah, penegakan hukum dan pemberian sanksi yang tegas serta. Kedua Upaya meminimalisir fraud tersebut harus dilaksanakan secara bersama-sama dan berkesinambungan. Keduanya harus saling mendukung satu sama lain agar dapat memberikan hasil yang optimal. 


\section{DAFTAR PUSTAKA}

Abdullah, thamrin (2012). Bank dan Lembaga Keuangan Lain Jakarta : Graham Ilmu

Adrian Sutedi, 2009, Perbankan Syariah: Tinjauan dan Beberapa Segi Hukum, Bogor; Ghalia Indonesia, cetakan pertama

Antonio, M. Syafi'i dkk. Bank Syariah "Analisis Kekuatan, Kelemahan, Peluang, dan Ancaman". Yogyakarta : Ekonisia, 2006.

Arikunto, Suharsimi. (2005). Manajemen Penelitian. Cetakan Ketujuh, Penerbit Rineka Cipta, Jakarta

Association of Certified Fraud Examiners (ACFE), 2014. Fraud Prevention and Detterence, Fraud Examiners Manual, International Edition (FPD)

Amin Widjaja Tunggal. 2001. Pemeriksaan Kecurangan (Fraud Auditing), Harvarindo, Jakarta.

Anonim. 2016. Kamus Besar Bahasa Indonesia Online. Kbbi.web.id. diakses pada tanggal 12 Agustus 2016, pukul 21.00 Wib. Pamekasan.

Budianto, Agus (2011), Mengkaji Kejahatan Korporasi Di Bidang Perbankan Dalam Sistem Perbankan Indonesia. Universitas Pelita Harapan Karawaci.

Hutauruk, Rapat Piter Sony, Se, (2014) Analisis Prosedur Pemberian Kredit Pada Pt. Bank Cimb Niaga Laju Tebing Tinggi, Jurnal Ilmiah Accounting Changes ,Stie Bina Karya Tebing Tinggi

Haryono, Slamet . (2009). Analisis Laporan Keuangan Perbankan Syariah .Yogyakarta: Pustaka Sayid Sabiq.

Holtfreter, Kristy (2003) Is occupational fraud typical white-collar crime? A comparison of individual and organizational characteristics, Journal of Criminal Justice 33.

Junaedi, Edy, (2013), Fraud Perbankan Syariah Dan Moralitas Keislaman, STAI AsySyukriyyah Tangerang

Kamayanti, Ari (2016), Metodologi Penelitian Kualitatif Akuntansi, Yayasan Rumah Peneleh

Kasmir (1998) Bank dan Lembaga Keuangan Lain Jakarta : Graham Ilmu

Muhammad. 2005. Bank Syariah Problem dan Prospek Perkembangan di Indonesia. Yogyakarta: Graha Ilmu.

Syafriansyah, Muhammat (2015), Analisis Sistem Dan Prosedur Pemberian Kredit Pada Koperasi Simpan Pinjam Sentosa Di Samarinda, Ejournal Ilmu Administrasi Bisnis

Sugiyono. 2009. Metode Penelitian Kuantitatif, Kualitatif dan $R \&$ D. Bandung : Alfabeta 
Sugiarto. (2010). Manajemen Resiko Perbankan. Jakarta : Graham Ilmu

Supomo, Nur Indriantoro. Bambang Supomo. 1999. “Metodologi Penelitian Bisnis”. BPFE. Yogyakarta.

Sukoharsono, Eko Ganis (2006), Alternatif Riset Kualitatif Sains Akuntansi: Biografi, Phenomenologi, Grounded Theory, Critical Ethnografi Dan Case Study, Universitas Brawijaya

Tuanakotta, Theodorus M. (2011). Manipulasi Laporan Keuangan. Jakarta: Salemba Empat

Triandaru, Sigit. (2008). Bank dan Lembaga Keuangan Lain. Jakarta: Salemba Empat

Tuanakotta, Theodorus M. (2010). Akuntansi Forensik \& Audit Investigatif(edisi 2). Jakarta: Salemba Empat

Yogi Prabowo, Hendi (2013), Curing Corruption In Indonesia: A Behavioral Perspective. International Conference on Financial Criminology (ICFC) 2013

Yin, Robert K, (2009), Case Study Research. Design and Methods 